\title{
Model Assumptions and Analysis of Ecological Awareness and Behaviour: an Empirical Study
}

\author{
Wiesław Piekarski ${ }^{1 *}$, Agnieszka Dudziak ${ }^{1}$, Monika Stoma ${ }^{1}$, \\ Dariusz Andrejko², Beata Ślaska-Grzywna² \\ ${ }^{1}$ Department of Power Engineering and Transportation, Subdepartment of Logistics and Business Management, \\ University of Life Sciences in Lublin \\ ${ }^{2}$ Department of Biological Bases of Food and Feed Technologies, University of Life Sciences in Lublin \\ Głęboka 28, 20-612 Lublin, Poland
}

Received: 31 March 2015

Accepted: 12 February 2016

\begin{abstract}
Ecological awareness and, consequently, certain types of human behaviour, are still debatable. The issues related to ecology and environmental protection still raise many doubts among various populations. This article presents the results of a survey conducted among respondents residing in southeastern Poland. Due to the multidimensional nature and complexity of the 'ecological awareness' category, the aim of the conducted research was to create a dimensional characteristics model providing the possibility to investigate the way in which the indicated category is perceived by the inhabitants of the southeastern part of Poland.

A list of primary features (determinants) allowing us to describe ecological awareness and behaviour was defined in order to achieve the indicated objective. Particular determinants of the category of 'ecological awareness' were linked to five key thematic areas. The respondents, exploiting a designed scale related to particular determinants, were asked to identify an appropriate level on a scale that was the closest to their attitudes toward awareness and ecological behaviour they identified with. The data collected in the research underwent a statistical analysis; in this case, it was a multivariate analysis. The investigation resulted in selecting a model of dimensional characteristics of 'ecological awareness' consisting of nine components (dimensions) that could serve as a tool for further analysis. It is worth noting that two dimensions — 'individual consciousness' and 'social awareness' - were distinguished within the model. It is of crucial importance for the conducted policy of individuals in the decision-making process concerning the environment, and on the other hand it denotes a growing individual awareness of inhabitants.
\end{abstract}

Keywords: ecological awareness, ecological behaviour, environmental protection, factor analysis 


\section{Introduction}

Recently, issues concerning environmental protection and, consequently, the problems of ecological awareness of society have been frequently discussed by both scientists and different countries. Ecological awareness denotes a human attitude to nature that features great responsibility for its condition. It stems from a thorough knowledge about nature as well as determination to preserve it in its primary state [1]. Its determinants include, inter alia, respect for nature, complying with rules concerning protection of nature, and counteracting environmental risks. Moreover, ecological awareness is sometimes perceived as the extent of residents' interest in nature and its protection, their opinions about environmental degradation, and their knowledge concerning possible actions enhancing wildlife conservation [2-4]. According to Burger [5] ecological awareness is a set of data and beliefs about nature and the perception of links between the state and the character of the natural environment and the conditions and the quality of human life. It is also people's attitudes toward the natural environment, the set of collected data and beliefs about it, and the system of values that direct human behaviour [6].

Thus, ecological awareness can be defined in both a descriptive and axiological-normative way. The descriptive and technical approach defines it as a totality of information and beliefs about the natural environment and the perception of links between the state and the character of the natural environment and the conditions and the quality of human life. However, in terms of axiologicalnormative categories, ecological awareness denotes a bio-centric system, i.e., understanding, experiencing, and evaluating the processes that take place in the biosphere and the whole set of interdependencies between society and nature, as well as the assessment of ecological ethics [5]. It is also a state of people's views and perceptions regarding the role of the environment in human life, our anthropogenic load, the degree of overexploitation, threats, and protection, including the state of knowledge about the methods and tools employed to manage, protect, and shape the environment [6].

Ecological awareness is a complex and multidimensional concept, and therefore the literature on the subject distinguishes its different types, sizes, shapes, and components. The basic typology allows for the identification of individual and social awareness. On the other hand, as regards the dimensions, it is possible to speak of real and ideal dimensions. Ecological awareness can be expressed in different forms; these are, inter alia: commonsense thinking, ideologies, public opinion, or scientific knowledge. Its components include: the emotional-evaluative component (system of values adopted by people and society), the cognitive component (the vision of the model of civilization and natural science), and the behavioural component (human needs and demands related to the use of natural wealth and individual activities for environmental protection).

According to Papuziński [7], ecological awareness is not only knowledge, views, and ideas about the environment. It is a paradigm that includes the values, ideas, and opinions about the environment in which an individual lives and operates the same as the all of society. On the other hand, according to Kalinowska [8], 'ecological awareness' is rather an ambiguous concept, referring to different situations and mental states, and therefore, several levels of this type of consciousness may be distinguished: firstly, one can deal with an intuitive belief that the existence of some element is threatened or puts the health or other needs of an individual at risk; secondly, an intuitive conviction can be combined with knowledge related to mechanisms of threats. The third level of ecological awareness is constituted by an emotional reaction to the observed reality.

Due to a lack of a comprehensive, universally accepted definition of ecological awareness, scientific bodies describing the term often cite its individual components, naming them in various ways. According to Mirowski [9], ecological awareness consists of:

- Ecological knowledge expressed through the acquaintance with and understanding of the means of coexistence between man and nature.

- Ecological sensitivity, or emotional attitude to nature.

- Pro-ecological attitude, or actions undertaken to protect the natural environment.

Environmental awareness has broad coverage, including relevant aspects such as geography, ecology, philosophy, environics, ethics, law, political science, and more. Some scholars believe that the basic meaning of environmental awareness includes natural concepts and values, environmental science and technology, environmental law and policy, environmental ethics, and environmental psychology [10].

Ecological behaviour, in turn, includes actions that may be undertaken by any human being and which exert a positive impact on the environment [11].

Studies on awareness and ecological actions of residents are being conducted in the world and in Poland as well. The Polish study in this field is carried out by the Ministry of the Environment within the framework of a long-term research program [12], and by the Institute for Sustainable Development [13].

The huge importance of ecological awareness in the process of shaping public attitudes toward the natural environment makes it an important category of research, especially in the area of the relationship between man and environment $[14,15]$. Also, the perception of environmental awareness by current and potential users of the environment as well as the identification and evaluation of attitudes and behaviours toward sustainable development issues and consequently the protection of the environment seem to be important issues in this field. It becomes, on the one hand, an important factor for making further analyses in this field and on the other it may be the starting point of educational or operational activities carried out by authorities at different levels concerning the promotion of ecological behaviour of both individuals and society as a whole. 
Table 1. List of determinants describing environmental awareness.

\begin{tabular}{|c|c|}
\hline \multicolumn{2}{|r|}{ Assessing local environment conditions } \\
\hline 1. & positive assessment of the general state of the environment \\
\hline 2. & improving the general state of the environment within the last five years \\
\hline 3. & air pollution - not present or slight \\
\hline 4. & water pollution - not present or slight \\
\hline 5. & soil degradation — not present or slight \\
\hline 6. & no significant environmental pollution by industry \\
\hline 7. & no significant noise (traffic or industrial) \\
\hline 8. & appropriate waste management (no illegal dumps, littering the forest, burning garbage, etc.) \\
\hline 9. & controlled discharge of household sewage \\
\hline 10. & introducing appropriate agricultural practices and proper fertilizers by farmers \\
\hline 11. & protection of valuable natural areas \\
\hline 12. & control of forest areas and no excessive deforestation \\
\hline 13. & high public awareness of the environment protection \\
\hline \multicolumn{2}{|r|}{ Assessing the environmental awareness of the residents } \\
\hline 14. & residents' sense of responsibility for the environment \\
\hline 15. & undertaking appropriate social actions to protect the environment \\
\hline 16. & sorting of waste by residents \\
\hline 17. & using eco-friendly means of transport, e.g., a bike or on foot by borough inhabitants \\
\hline 18. & limiting consumption of media \\
\hline 19. & the use of reusable bags while shopping by residents of the borough \\
\hline 20. & social involvement in activities for environmental protection \\
\hline \multicolumn{2}{|r|}{ Assessing individual actions for the protection of the environment } \\
\hline 21. & high individual awareness regarding environment protection \\
\hline 22. & individual sense of responsibility for the environment \\
\hline 23. & undertaking appropriate individual actions for environmental protection \\
\hline 24. & a proposal of introducing a small voluntary tax to protect the environment \\
\hline 25. & sorting of waste in the household \\
\hline 26. & individual exploitation of eco-friendly means of transport, e.g, a bike or on foot \\
\hline 27. & individual limiting consumption of media (e.g., water) \\
\hline 28. & individual use of reusable bags (organic materials, paper) while shopping \\
\hline 29. & individual participation in environmental protection activities \\
\hline \multicolumn{2}{|r|}{ Assessing the effectiveness of the local authorities' actions in the field of environmental protection } \\
\hline 30. & undertaking sufficient actions by the authorities regarding environmental protection \\
\hline 31. & undertaking sufficient actions by the authorities regarding environmental protection in the voivodeship \\
\hline 32. & organizing actions aimed at promoting environmental protection by the municipal authorities \\
\hline 33. & organizing actions aimed at promoting environmental protection by the voivodeship authorities \\
\hline 34. & a need for more activities aimed at raising the ecological awareness of residents of the borough/voivodeship \\
\hline 35. & a need for more activities aimed at improving the state of the environment \\
\hline 36. & proposing higher penalties/fines for pollution to be introduced by authorities \\
\hline 37. & more containers for sorting waste are needed \\
\hline
\end{tabular}


Table 1. Continued.

\begin{tabular}{|c|c|}
\hline \multicolumn{2}{|c|}{ Knowledge and its sources concerning the environment and its protection } \\
\hline 38. & $\begin{array}{c}\text { individual participation in local ecological education campaigns (e.g., picnics, organic festivals, 'Clean Up the World' activi- } \\
\text { ties, etc.) }\end{array}$ \\
\hline 39. & adequate transfer of information about ecology and environmental protection by the educational system \\
\hline 40. & acquiring knowledge about the condition and environmental protection issues from the media \\
\hline 41. & $\begin{array}{c}\text { acquiring knowledge about the condition and environmental protection issues from various actions and environmental cam- } \\
\text { paigns }\end{array}$ \\
\hline 42. & $\begin{array}{c}\text { acquiring knowledge about the condition and environmental protection issues from the information provided by the office of } \\
\text { the city/municipality }\end{array}$ \\
\hline 43. & knowledge of the concept of 'sustainable development' \\
\hline 44. & proposing high penalties for businesses that are major polluters \\
\hline 45. & the environment is more important than economic growth \\
\hline 46. & greance of environmental protection against pollution for municipal/businesses income growth \\
\hline
\end{tabular}

Source: the authors' own studies

Taking into account the above, the following research problems were formulated:

- Can a multidimensional model that describes a category of environmental awareness be developed with the use of factor analysis?

- Can individual dimensions that make up the analysed model of dimensional characteristic be described in a consistent and unambiguous manner?

Therefore, having in mind the multidimensionality and the complexity of the indicated category, the aim of the conducted research was to develop a model of dimensional characteristics concerning the category of 'ecological awareness,' allowing us to investigate the way in which some inhabitants of southeastern Poland perceive the category.

\section{Material and Research Methods}

Source material data were obtained on the basis of the survey, conducted with the help of a structured questionnaire. The starting point in the research process was drafting the five main thematic areas:

1. Assessing the local environment conditions.

2. Assessing the environmental awareness of the residents.

3. Assessing individual actions for the protection of the environment.

4. Assessing the effectiveness of the local authorities' actions in the field of environmental protection.

5. Knowledge of sources concerning the environment and its protection.

... to which relevant determinants were matched in order to describe ecological awareness and activities (Table 1).

The list of the indicated determinants was designed on the basis of literature studies and with respect to the analysis of the specificity of the investigated issue. Due to the fact that the relationships among particular aspects are unknown, an exploratory approach was applied, i.e., the features characterizing the investigated object were selected in such a way as to describe it in the broadest and most exhaustive manner possible, and at the same time so that they are not correlated with each other too closely because it may result in a duplication of information on the analysed phenomenon, and as a consequence lead to incorrect conclusions. In addition, the number of determinants that must be applied to determine the object of the research should be relatively high because it contributes to an extensive perception [16].

The designed measurement tool in the form of a questionnaire survey consisted of 46 statements of positive connotations, whose semantic content corresponded to particular determinants of the primary determinants list. A five-step Likert scale was implemented, in which particular categories of responses were assigned scores (from 1 - "I disagree" to 5 - "I agree") in order to evaluate the theorems. The categories of scale from 1 to 2 denoted a negative attitude, whereas the categories from 4 to 5 denoted a positive attitude and, finally, the third category meaning 'no opinion' was a neutral category. The respondents were asked to select one of the levels of scale for each theorem that reflected their attitude to it in the best possible manner. The metrics were attached to the survey and it included sets of questions identifying respondents' descriptive features such as gender, age, education, place of residence, and profession.

The data provided by the questionnaires underwent statistical analysis supported by factor analysis, allowing us to generate unobservable, hidden (latent), values assessed by the respondents on the basis of a fixed set of diagnostic variables (variables recorded empirically); i.e., it allows for the transformation of the output, mutually correlated layout of variables to get a new system of variables (i.e., the common factors or principal components) mutually uncorrelated, but comparable with the output. In view of the aforementioned assumption, the aggregation of 
Table 2. Socio-demographic profile of the population surveyed.

\begin{tabular}{|c|c|c|}
\hline $\begin{array}{l}\text { Socio-demographic } \\
\text { profile }\end{array}$ & $\begin{array}{l}\text { Number of } \\
\text { respondents }\end{array}$ & $\begin{array}{l}\text { Percentage } \\
\text { share }\end{array}$ \\
\hline Total & 188 & - \\
\hline \multicolumn{3}{|c|}{ Gender } \\
\hline male & 104 & 55.3 \\
\hline female & 84 & 44.7 \\
\hline \multicolumn{3}{|c|}{ Age } \\
\hline to 18 years & 14 & 7.4 \\
\hline $19-25$ years old & 139 & 73.9 \\
\hline $26-55$ years old & 32 & 17.1 \\
\hline 56 years and more & 3 & 1.6 \\
\hline \multicolumn{3}{|c|}{ Education } \\
\hline primary & 43 & 22.9 \\
\hline secondary & 83 & 44.1 \\
\hline university & 62 & 33.0 \\
\hline \multicolumn{3}{|c|}{ Place of residence } \\
\hline rural area & 89 & 47.3 \\
\hline city of up to 300,000 residents & 47 & 25.0 \\
\hline $\begin{array}{c}\text { city of more than } 300,000 \\
\text { residents }\end{array}$ & 52 & 27.7 \\
\hline
\end{tabular}

Source: the authors' own studies

the primary determinants with the use of the principal component analysis with Varimax normalized rotation of the output variable space was made. The aim of the rotation was to obtain a clear structure of factors, i.e., the factors that may be distinguished by high loads on some variables and low loads on other variables [17].

To determine the number of factors, the "method of the percentage of variance translated by the main factors' was implemented; the factors were being determined until the sum of their variance accounted for at least $70 \%$ of the total variance of all the observable variables, and none of the next ones explained more than $5 \%$. In order to verify the number of factors, the Kaiser test method (a method of eigenvalue greater than unity) was additionally applied. The method was based on the fact that only those factors are left that display eigenvalues greater than unity [18]. The Kaiser criterion should be used when the number of variables to be evaluated by the respondents is greater than 20.

The orthogonal factors selected in the aforementioned way were then investigated to identify their internal structure, to interpret the relationship between them, and to name the resulting factors through the semantic content analysis of the variables with the highest factor loadings. In consequence, it enhanced the formulation of an ecological awareness model of these inhabitants of southeastern Poland.
The survey was conducted in 2014. It involved 188 respondents who reside in southeastern Poland, in the Lubelskie, Podkarpackie, and Świętokrzyskie voivodeships. In order to determine the number of the respondents, the conditionings employed in the statistical analysis methods (especially factor analysis) were taken into consideration. The indicated analysis requires a sample to be taken out of the population of at least 100 to 200 people [16].

The research was incomplete, and the incidental community survey method was implemented to select the respondents. The surveys were anonymous, and at the outset each respondent was informed about the general purpose of the research. The questions directed at the respondents addressed the issues related to the current state of the environment, ecological behavior, and the level of environmental awareness of the inhabitants of southeastern Poland. Additionally, the respondents' knowledge of environmental threats was tested and their specific types of activities and attitudes toward the environment were considered.

In order to describe the structure of the population and particular variables, the data provided by the empirical material underwent a statistical analysis using the Statistica 10 program. The results of the analysis were presented in graphical, tabular, and narrative forms.

\section{Research Results}

Information obtained through research enhanced the possibility of characterizing the respondents in terms of gender, age, education, place of residence, and profession. The demographic and social characteristics of the respondents are presented in Table 2.

In order to aggregate the primary variables and to make the structure analysis of the selected factors, the main components have been investigated. The analysis included data $(n=188)$ obtained through research. The eigenvalues of the selected factors, the variance shares accounted for by individual factors, and the cumulative variance are displayed in Table 3, which shows that the cumulative variance (which includes the variability expressed by separate factors) amounts to more than $74 \%$. By contrast, Fig. 1 shows the scree chart, the line indicating the level of the eigenvalue corresponding to the Kaiser rule.

Afterward, as a result of the main components analysis with factor rotation made with the standard Varimax method, 16 mutually orthogonal factors were selected. While interpreting the structure of each factor, only the loads of variables with a value greater than 0.500 were taken into account. In cases of factors difficult to interpret in terms of structure, the auxiliary variables described by loads of $>0.400$ were exploited. The overriding principle applied at this point was the substantive consistency principle (the search for the semantic consistency of variables forming a given factor, and consequently the integration of variable content to form a meaningful name sensibly expressing the content included in them), which 
Table 3. Eigenvalues, $\mathrm{n}=188$.

\begin{tabular}{|c|c|c|c|c|}
\hline Factor number & Eigenvalue & $\%$ of the total variance & Cumulative eigenvalue & Cumulative \% of variance \\
\hline 1 & 6.307301 & 13.71152 & 6.30730 & 13.71152 \\
\hline 2 & 5.504465 & 11.96623 & 11.81177 & 25.67775 \\
\hline 3 & 2.788098 & 6.06108 & 14.59986 & 31.73884 \\
\hline 4 & 2.399674 & 5.21668 & 16.99954 & 36.95552 \\
\hline 5 & 2.084375 & 4.53125 & 19.08391 & 41.48677 \\
\hline 6 & 1.915544 & 4.16423 & 20.99946 & 45.65100 \\
\hline 7 & 1.786216 & 3.88308 & 22.78567 & 59.53407 \\
\hline 8 & 1.597747 & 3.47336 & 24.38342 & 56.35991 \\
\hline 9 & 1.542138 & 3.35247 & 25.92556 & 59.34247 \\
\hline 10 & 1.371978 & 2.98256 & 27.29754 & 62.21172 \\
\hline 11 & 1.319854 & 2.86925 & 28.61739 & 64.85272 \\
\hline 12 & 1.214858 & 2.64100 & 29.83225 & 67.38083 \\
\hline 13 & 1.162930 & 2.52811 & 30.99518 & 69.86095 \\
\hline 14 & 1.140856 & 2.48012 & 32.13604 & 72.21416 \\
\hline 15 & 1.082480 & 2.35322 & 33.21852 & 74.40218 \\
\hline 16 & 1.006485 & 2.18801 & 34.22500 & \\
\hline
\end{tabular}

Source: the authors' own studies

constituted the basis for the inclusion of a given variable in the structure of the factor under consideration.

During the analysis and interpretation of the particular factors' internal structure, it turned out that in some cases the semantic content was found to be similar. Therefore, in regards to seven factors, the aggregation with five other agents was made (factor 1 was combined with 12; 4 with $5 ; 6$ with 8 ; 9 with 10,13 , and 16; and 11 with 14). Nine factors were obtained as a result of this operation. The semantic content analysis of particular factors was included in Table 4 showing the verbal structures of each dimension of the considered issue.

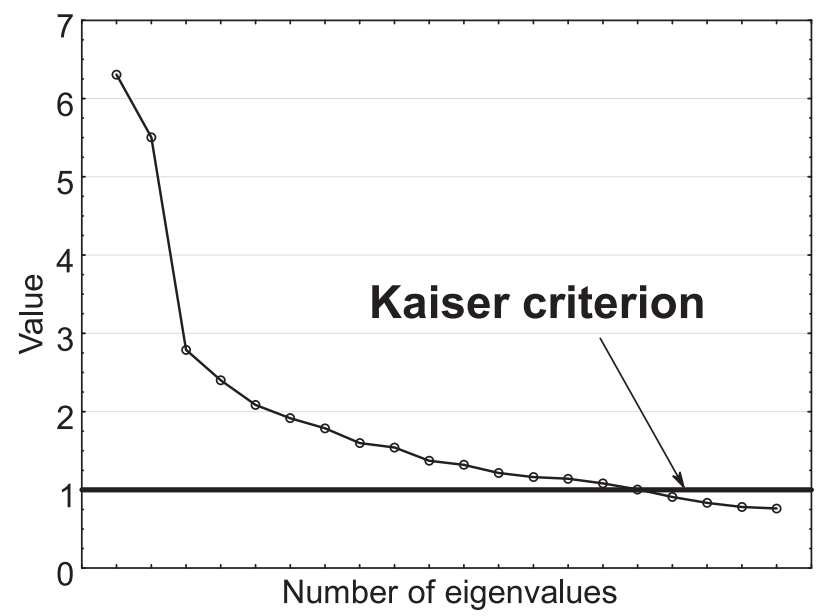

Fig. 1. Chart of eigenvalues (scree), $\mathrm{n}=188$.

Source: the authors' own studies
Therefore, the model of the dimensional characteristics of the category of ecological awareness can be expressed through the form of a sentence, which is:

$$
\mathrm{UUA}=\mathrm{f}\left(\mathrm{x}_{\mathrm{OEA}}, \mathrm{x}_{\mathrm{IA}}, \mathrm{x}_{\mathrm{SA}}, \mathrm{x}_{\mathrm{A}}, \mathrm{x}_{\mathrm{SD}}, \mathrm{x}_{\mathrm{EMT}}, \mathrm{x}_{\mathrm{SMW}}, \mathrm{x}_{\mathrm{EE}}, \mathrm{x}_{\mathrm{IE}}\right)
$$

...where:

$-\mathrm{x}_{\mathrm{OEA}}$ is overall environmental assessment

$-\mathrm{x}_{\mathrm{IA}}$ is individual awareness

$-\mathrm{x}_{\mathrm{SA}}$ is social awareness

$-\mathrm{x}_{\mathrm{A}}$ is actions to protect the environment

$-\mathrm{x}_{\mathrm{SD}}$ is sustainable development and financial responsibility

$-\mathrm{x}_{\mathrm{EMT}}$ is ecological means of transport

$-\mathrm{x}_{\mathrm{SMW}}$ is sustainable management of waste

$-\mathrm{x}_{\mathrm{EE}}$ is ecological education

$-\mathrm{x}_{\mathrm{IE}}$ is improvement of the environment

\section{Discussion of Results}

Particular determinants (primary features) of the considered category of 'ecological awareness' were linked to the five primary thematic areas, identified in the section 'Material and research methods.' Based on the designed list of primary features, the measurement tool was developed, and it was a questionnaire consisting of 46 statements about the positive connotations, whose semantic content matched the particular points of the primary dimensional characteristics as regards the tested category. As a result of the conducted research and the 
Table 4. The dimensional characteristics of the investigated factors.

\begin{tabular}{|c|c|}
\hline The name of the factor & The factor structure \\
\hline $\begin{array}{l}\text { Factor 1: general charac- } \\
\text { teristics of the environ- } \\
\text { ment }\left(\mathrm{x}_{\mathrm{OEA}}\right)\end{array}$ & $\begin{array}{l}\text { 6: no significant environmental pollution by industry } \\
\text { 5: soil degradation - not present or slight } \\
\text { 1: positive assessment of the general state of the environment } \\
\text { 3: air pollution - not present or slight } \\
\text { 4: water pollution - not present or slight } \\
\text { 11: protection of valuable natural areas }\end{array}$ \\
\hline $\begin{array}{l}\text { Factor 2: individual } \\
\quad \text { awareness }\left(\mathrm{x}_{\mathrm{IA}}\right)\end{array}$ & $\begin{array}{l}\text { 22: individual sense of responsibility for the environment } \\
\text { 23: undertaking appropriate individual actions for environmental protection } \\
\text { 21: high individual awareness regarding environmental protection } \\
\text { 25: sorting of waste in the household }\end{array}$ \\
\hline $\begin{array}{l}\text { Factor 3: social } \\
\text { awareness }\left(\mathrm{x}_{\mathrm{SA}}\right)\end{array}$ & $\begin{array}{l}\text { 9: controlled discharge of sewage from households } \\
\text { 10: introducing appropriate agricultural practices and proper fertilizers by farmers } \\
\text { 13: high public awareness of environmental protection } \\
\text { 15: undertaking appropriate social actions to protect the environment } \\
\text { 11: protection of valuable natural areas }\end{array}$ \\
\hline $\begin{array}{l}\text { Factor 4: actions to pro- } \\
\text { tect the environment }\left(\mathrm{x}_{\mathrm{A}}\right)\end{array}$ & $\begin{array}{l}\text { 32: organizing actions aimed at promoting environmental protection municipal authorities } \\
\text { 33: organizing actions aimed at promoting environmental protection by voivodeship authorities } \\
\text { 29: individual participation in environmental protection activities } \\
\text { 20: social involvement in activities for environmental protection } \\
\text { 38: individual participation in local ecological education campaigns (e.g., picnics, organic festivals, } \\
\text { 'Clean Up the World' activities, etc.). }\end{array}$ \\
\hline $\begin{array}{l}\text { Factor 5: sustainable } \\
\text { development and financial } \\
\text { responsibility }\left(\mathrm{x}_{\mathrm{SD}}\right)\end{array}$ & $\begin{array}{l}\text { 45: greater importance of environment protection against pollution than municipal/businesses income } \\
\text { growth } \\
\text { 24: a proposal of introducing a small voluntary tax to protect the environment } \\
\text { 46: the environment is more important than economic growth } \\
\text { 44: proposing high penalties for businesses that are major pollutants } \\
\text { 36: proposing higher penalties/fines for pollution to be introduced by authorities }\end{array}$ \\
\hline $\begin{array}{c}\text { Factor 6: ecological } \\
\text { means of transport }\left(\mathrm{x}_{\mathrm{EMT}}\right)\end{array}$ & $\begin{array}{l}\text { 26: individual exploitation of eco-friendly means of transport, e.g., a bike or on foot } \\
\text { 17: using eco-friendly means of transport, e.g., a bike or on foot by borough inhabitants }\end{array}$ \\
\hline $\begin{array}{l}\text { Factor 7: sustainable } \\
\text { management of waste } \\
\qquad\left(\mathrm{x}_{\mathrm{SMW}}\right)\end{array}$ & $\begin{array}{l}\text { 42: knowledge on the concept of 'sustainable development' } \\
\text { 8: appropriate waste management (no illegal dumps, littering the forest, burning garbage, etc.) } \\
\text { 16: sorting of waste by residents } \\
\text { 28: individual use of reusable bags (organic materials, paper) while shopping } \\
\text { 25: individual sorting of waste in the household } \\
\text { 19: the use of reusable bags while shopping by residents of the borough } \\
\text { 37: more containers for sorting waste needed }\end{array}$ \\
\hline $\begin{array}{l}\text { Factor 8: ecological } \\
\quad \text { education }\left(\mathrm{x}_{\mathrm{EE}}\right)\end{array}$ & $\begin{array}{l}\text { 40: acquiring knowledge about the condition and environmental protection issues from the media } \\
\text { 30: undertaking sufficient actions by the authorities regarding environmental protection } \\
\text { 31: undertaking sufficient actions by the authorities regarding environmental protection in the voivode- } \\
\text { ship } \\
\text { 34: a need for more activities aimed at raising the ecological awareness of residents of the borough/ } \\
\text { voivodeship }\end{array}$ \\
\hline $\begin{array}{l}\text { Factor 9: the improve- } \\
\text { ment of the environment } \\
\qquad\left(\mathrm{x}_{\mathrm{IE}}\right)\end{array}$ & 2: improving the general state of the environment within the last five years \\
\hline
\end{tabular}

employment of the principal components analysis with the normalized Varimax rotation, a model of a nine-word form was obtained (pattern 1).

According to our respondents' opinions as revealed in the survey, the category of 'ecological awareness' consists of nine major dimensions (pattern 1 and Table 4). It shows that 'ecological awareness' is a very complex and multidimensional category of which particular dimensions include separate semantic content $[19,20]$.

Attention should be paid to the dimensions distinguished within the model, defined as individual consciousness' and 'social awareness.' It corresponds to the views of other authors, including, inter alia, Ridei et al. [21], according to whom the category of 'ecological awareness' constitutes a vast area of both individual and social awareness, related to multidirectional and humanenvironment relations at various levels. In the individual dimension, that term refers to individual experiences and the way of thinking about nature, whereas in the collective dimension it refers to the standards of perception, experience, and evaluation of the biosphere. Some authors [22-25] indicate that environmental awareness is enhanced 
by an individual's increased environmental awareness and understanding of the systems.

Poles start to appreciate the importance of individual participation in the decision-making process concerning the environment in which they live. They become increasingly aware of the impact they exert on the process of shaping the environment that surrounds them, and they stress it more and more clearly so that they expect actions and responsibility for the state of the environment on the part of local authorities and in active attitudes of society $[13,26]$. The more environmentally aware an individual, the more conscious actions he or she can take regarding environmental protection $[27,28]$. People are an integral part of nature, and natural destruction results in our own harm. This is very important because environmental threats affect not only every individual but also each type of business, and above all each country [29].

The natural environment is in a state of constant deterioration, and modern societies face the need to search for more efficient ways of sustainable development, and in consequence more effective means of taking care of the surrounding nature. Therefore, knowledge concerning both the elements of ecological awareness and its sociodemographic determinants may enhance the design and the implementation of educational activities. This indicates the close relationship between sociology and ecology, particularly in the sphere of social ecology.

The created model of dimensional characteristics of the category of 'ecological awareness' can serve as a starting point for further research, helpful in determining the assessment of validity coefficients for each model parameter. It would be advisable to design another measurement tool in the form of a questionnaire to measure the load of features concerning the formulated dimensional characteristics. In order to determine the validity coefficients it is possible to employ the S Siegel test, which is indispensable for determining the degree of convergence of the obtained assessment data due to the fact that in the proposed research, we deal with a set of consecutive feature validity assessments made by a group of respondents. Therefore, it is necessary to calculate the W Kendall concordance coefficient. The aforementioned statistics provide the answer to the question on how similar the distribution of answers to $n$ questions among $k$ competent judges is, assuming that the judges assess independently of one another, and that each of them is able to use the assessment criteria in a reliable manner.

\section{Conclusions}

On the basis of literature studies, empirical research, acquired data, and their analysis and discussion, the following conclusions have been made:

1. The use of factor analysis - the analysis of main components with the normalized Varimax rotation allows for the construction of a model of dimensional characteristics of the category of environmental awareness.
2. The category of 'ecological awareness' is a complex and multi-dimensional issue that may be considered in a variety of contexts and at different levels.

3. Our own empirical research allowed us to indicate the category of 'ecological awareness' by means of a dimensional characteristics model consisting of nine components (dimensions): general assessment of the environment, individual consciousness, social awareness, actions to protect the environment, sustainability and financial responsibility, eco-friendly means of transport, sustainable waste management, environmental education, and a better environment.

4. The created dimensional characteristics model of the category of 'ecological awareness' is the starting point for further research helpful in determining the assessment of validity coefficients for each model parameter using the S Siegel test and W Kendall concordance coefficient.

"Nature knows neither reward nor punishment, it knows only the consequences"

(R. Ingesoll)

\section{References}

1. KOLlMUSS A., AGYEMAN J. Mind the gap: why do people act environmentally and what are the barriers to proenvironmental behaviour? Environ. Educ. Res. 8 (3), 239, 2002.

2. SCHULTZ P.W., SHRIVER C., TABANICO J., KHAZIAN A.M. Implicit connections with nature. J. Environ. Psychol. 24, 31, 2004.

3. GADENNE D.L., KENNEDY J., MCKEIVER C. An empirical study of environmental awareness and practices in SMEs. J. Bus. Ethics 84, 45, 2009.

4. MÄLGAND M., BAY-MORTENSEN N., BEDKOWSKA B., HANSEN F.N., SCHOW M., THOMSEN A.A., HUNKA A.D. Environmental awareness, the Transition Movement, and place: Den Selvforsynende Landsby, a Danish Transition initiative. Geoforum 57, 40, 2014.

5. BURGER T. Environmental awareness of Polish community. Instytut Gospodarki i Przestrzeni Miejskiej, Warszawa, 300, 2005 [In Polish].

6. PRÉVOT-JULLIARD A.C., CLAVEL J., TEILLACDESCHAMPS P., JULLIARD R. The Need for Flexibility in Conservation Practices: Exotic Species as an Example. Environ. Manage. 47, 315, 2011.

7. PAPUZIŃSKI A. Ecological awareness in the light of theory and practice. Problems of Ecology, 1, 33, 2006 [In Polish].

8. KALINOWSKA A. Ecology - the choice of the future. Warszawa, 273, 1997 [in Polish].

9. MIROWSKI W. Environmental awareness and sustainability [in:] Issues of science studies, 3, 1996 [in Polish].

10. LI J., DAN LIU D., LIU L. The Effect of Environmental Awareness on Consumers' Green Purchasing: Mediating Role of Green Perceived Value. [In:] Qi E., Shen J., Dou R. (ed.) The 19th International Conference on Industrial Engineering and Engineering Management, 767, 2013.

11. MILFONTA T.L., DUCKITT J. The environmental attitudes inventory: A valid and reliable measure to assess the structure of environmental attitudes. J. Environ. Psychol., 30, 80, 2010. 
12. http://www.mos.gov.pl/artykul/4770 badanie swiadomosci_2011/18296_badanie_swiadomosci_ ekologicznej_2011.html

13. http://www.ine-isd.org.pl/

14. BEST H. Environmental concern and the adoption of organic agriculture. Soc. Natur. Resour. 23 (5), 451, 2010.

15. KLÖCKNER C.A. A comprehensive model of the psychology of environmental behaviour - A meta-analysis. Global Environmental Change 23, 1028, 2013.

16. ZAKRZEWSKA M. Factor analysis in the construction and verification of the psychological models, Wyd. Nauk. UAM, Poznań, 40, 1994 [In Polish].

17. SEGARRA-OÑA M., PEIRÓ-SIGNES A., MONDÉJARJIMÉNEZ J. Identifying Variables Affecting the Proactive Environmental Orientation of Firms: An Empirical Study. Pol. J. Environ. Stud. 22 (3), 873, 2013.

18. KAISER H.F. Solution for the communalities. A preliminary report, Research Report, Berkeley, California, 5, 19, 1956.

19. MARQUART-PYATT S.T. Contextual influences on environmental concerns cross-nationally: A multilevel investigation. Social Science Research 41, 1085, 2012.

20. CSUTORA M. One More Awareness Gap? The BehaviourImpact Gap Problem. J Consum Policy 35, 145, 2012.

21. RIDEI N., RYBALKO Y., KYCHERENKO Y., PALAMARCHUK S., SHOFOLOV D. The role of ecological culture as an indicator of sustainable development of relations between society and nature. European Scientific Journal 2, 14, 2013.
22. CHAN E.S.W., HAWKINS R. Attitude towards EMSs in an international hotel: an exploratory case study. International Journal of Hospitality Management 29 (4), 641, 2010.

23. OAKLEY R.L., SALAM A.F. Examining the impact of computer-mediated social networks on individual consumerism environmental behaviors. Comput. Hum. Behav. 35, 516, 2014.

24. SAFFORD T.G., NORMAN K.C., HENLY M., MILLS K.E., LEVIN P.S. Environmental Awareness and Public Support for Protecting and Restoring Puget Sound. Environ. Manage. 53, 757, 2014.

25. CROTTY J., HALL S.M. Environmental Awareness and Sustainable Development in the Russian Federation. Sustain. Dev., 22 (5), 311, 2014.

26. CBOS, Environmental behavior of Poles, Warszawa 2011 [In Polish].

27. SZYSZLAK-BARGŁOWICZ J., SŁOWIK, T., ZAJĄC G., PIEKARSKI W. Inline Plantation of Virginia Mallow (Sida hermaphrodita R.) as Biological Acoustic Screen. Annual Set The Environment Protection, 15 (1), 524, 2013.

28. WANG S., LIU J., WANG R., NI Z., XU S., SUN Y. Impact of socioeconomic development on ecosystem services and its conservation strategies: a case study of Shandong Province, China. Environ Monit Assess 184, 3213, 2012.

29. AKCA H., SAYILI M., YILMAZCOBAN M. Rural Awareness of Environmental Issues: the Case of Turkey. Polish J. of Environ. Stud. 16 (2), 177, 2007. 